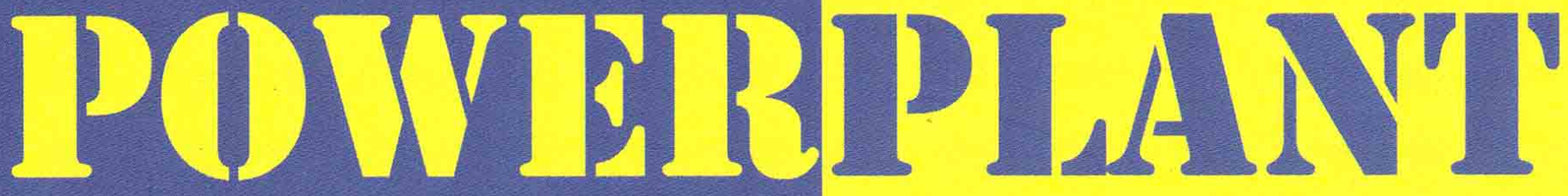

Nofirman:

Yusuf Rasyid

Vendy Antono;

Win Alfalah;

Rizky Windani

Eko Sulistiyo:

Utami Wahyuningsih:

M. Arif Rahman Sutisna

Sahlan

Vendy Antono;

Arief Suardi Nur Chairat;

Muhammad Husnuddin

Prayudi:

Roswati Nurhasanah

Hendri;

Suhengki:

Amru Fathony Lubis

Sri Yayi:

Jumiati;

Intan Ratna Sari Yanti
Pengaruh Kegagalan Terhadap Kinerja Chiller

Analisa Kegagalan Platen Tube SUperheater PLTU Teluk Sirih

Analisis Head Losses Pada Penstok Unit III Di Perum Jasa Tirta II Unit Jasa Pembangkit PLTA Ir. H.Djuanda

Kajian Terkait Industri Material HANKAM Dan

Kebencanaan Dari Sisi Pasar

Analisa Kerusakan Roda Gigi Cacing Pada Gearbox Air Preheater PLTU UJP Banten 3 Lontar Unit 1

Studi Eksperimental Kinerja Clod Strorage Mini dengan Refrigerant R2 dan R404A

Pengaruh Fouling Terhadap Laju Perpindahan Panas Pada Superheater Boiler CFB PLTU Sebalang

Pengaruh Jenis Pengetahuan Dan Kecakapan Terhadap Kemampuan Menulis Bahasa Inggris Pada Mahasiswa Teknik Mesin Sekolah Tinggi Teknik PLN

\begin{tabular}{|c|c|c|c|c|c|c|}
\hline$\|\mid\|$ & & SE & OLAH & VGGI TEKI & PL & \\
\hline
\end{tabular}




\title{
STUDI EKSPERIMENTAL KINERJA CLOD STRORAGE MINI DENGAN REFRIGERANT R2 DAN R404A
}

\author{
Prayudi ${ }^{1, a}$, dan Roswati Nurhasanah ${ }^{2, b}$ \\ ${ }^{1,2}$ Jurusan Teknik Mesin STT- PLN, Menara PLN Jl Lingkar Luar Barat Duri Kosambi Cengkareng \\ Jakarta Barat Indonesia, 11750 \\ aprayudi@sttpln.ac.id; ${ }^{b}$ roswati@sttpln.ac.id
}

\begin{abstract}
Abstrak
Untuk meningkatkan kapasitas efek refrigerasi dari sistem refrigerasi kompresi uap telah dikembangkan teknologi penukar kalor subcooling. Peningkatkan kapasitasnya tergantung pada efektivitas penukar kalor liquid suctionnya. Refrigerant $R 22$ adalah refrigerant yang merusak ozon, dan R404A adalah refrigerant yang tidak merusak ozon. Pada penelitian eksperimentah ini akan dilakukan dengan tujuan untuk mengetahui karakteristik R404A sebagai substitusi dari R22. Analisis kinerja pengaruhnya ditinjau dari efektvitas penukar kalor subcooling liquid suction terhadap perubahan rasio tekanan kompresor, COP, RCI, derajad sub cooling terhadap COP. Dari penelitian diperoleh hasil bahwa temperatur evaporator pada kondisi stabil dengan R404A lebih rendah dari pada $R 22$ baik menggunakan atau tanpa penukar kalor subcool, kapasitas refrigerasi $R 22$ lebih besar daripada menggunakan R404A. Kerja kompresor dengan refrigerant campuran R290/R600a lebih besar daripada R404a, adanya subcool kerja compressor reltif tidak berubahCOP dengan campuran R290/R600a lebih besar daripada R404a, dan adanya subcool akan mengakibatkan COP menurun. Secara umum dapat dikatakan bahwa R404A dapat digunakan sebagai pengganti dari R22
\end{abstract}

Kata kunci : subcooling liquid suction, penukar kalor, refrigerant $R 22$ dan $R 404 A$

\section{PENDAHULUAN}

Dewasa ini terdapat tiga isu utama dalam sistem refrigerasi siklus kompresi uap yakni penghematan energi, tuntutan refrijeran non ODS (Ozon Depleting Substable) dan non-GWP (Global Warning Potential). Sesuai kesepakatan Montreal Protocol 1987, refrigerant R22 yang merusak lingkungan akan dihapuskan mulai Januari 1996, dan R404A akan dihapuskan mulai tahun 2020 (Sattar,2007).

Untuk meningkatkan kinerja sistem refrigerasi kompresi uap biasanya digunakan metode antara lain (i) sub cooling atau pendinginan awal sebelum masuk evaporator, (ii) liquid pressure amplification, dan (iii) penambahan zat adiktif dalam refrigerant (Wankhede, U.S, 2009). ASHRAE menyatakan efektivitas penukar kalor sub-cooling digunakan untuk (i) meningkatkan kinerja sistem (ii) cairan refrigerant sudah pada kondisi sub-cooling sebelum masuk dalam inlet ekspansi valve. (iii) tidak ada cairan yang keluar evaporator sebelum masuk suction compressor. Penukar panas subcooling hanyalah tool (alat) yang dapat digunakan untuk mengevaluasi dampak refrigerant pada peningkatan kinerja dan kapasitas system refrigerasi (Bolaji B.O., Akintunde M.A., Falade T.O, 2010).

Beberapa penelitian menambahkan penukar kalor subcooling pada system refrigerasi kompresi uap. Penelitian liquid sub-cooling (Bolaji, B.O, Akintunde, M.A., Falade, T.O, 2010) dengan menggunakan lima refrigerant R23, R32, R134a, R134a dan R152a yang dipilih berdasarkan kriteria inflammability, toxicity dan atmospheric lifetime sebagai pengganti R12. Hasil penelitian diperoleh hasil bahwa penggunaan refrigerant R152a, R134a dan R143a dalam system refrigerasi kompresi uap dengan sub-cooling kinerjanya lebih baik dari pada R23 dan R32.

Beberapa penelitian telah dilakakukan untuk mencari pengganti refrigerant jenis R22 dengan refrigerant R410A, R507A, R417A dan $\mathrm{R} 407 \mathrm{C}$ pada temperature evaporasi $-15^{\circ} \mathrm{C}$ s.d $15^{\circ} \mathrm{C}$. Dari hasil penelitian diperoleh bahwa R410A dan R407C memiliki sifat fisik dan termodinamika dan kinerja mendekati R22. Dengan membandingkan COP, rasio tekanan yang diuji dan dampak lingkungan terhadap ozone, refrigerant R410A dan R407C pengganti refrigerant R22 (Paharia, Ashish Kumar and Gupta, R.C., 2013). Penelitian (Xu, Lihan and 
HRNJAK, Pega, 2014) Penelitian (Bolaji, 2012). Rocca dan Panno, 2011, melakukan penelitian untuk mengganti R-22 dengan refrigerant jenis HFC yaitu R.417A, R422A dan R422D. Hasil penelitian memperlihatkan bahwa kosumsi energy refrigerant pengganti semua lebih rendah dari pada R22. Penelitian juga membuktikan bahwa tiga refrigerant dapat digunakan sebagai pengganti tanpa menggati oli refrigerant dan tanpa melakukan modifikasi system dan aksesorisnya.

Dari berbagai penelitian diatas, dapat disimpulkan bahwa retrofit penggantian refrigerant jenis CFC R22 dengan refrigerant jenis $\mathrm{HCFC}$ yang bebas $\mathrm{ODP}=0$. Oleh karena itu masih terbuka luas untuk melakukan penelitian untuk mengganti refrigerant R22 dengan refrigerant jenis HCFC seperti R404A tanpa melakukan pengganti komponen dengan subcooling yang bekerja pada temperature evaporasi sampai dengan $-40^{\circ} \mathrm{C}$, dan temperature kondensasi antara $45^{\circ} \mathrm{C}-54^{\circ} \mathrm{C}$ dengan temperature ambient antara $33^{\circ} \mathrm{C}-36^{\circ} \mathrm{C}$.

\section{KAJIAN PUSTAKA}

Hasil penelitian sebelumnya membuktikan bahwa kenaikan subcooling kondensor, COP maksimum dihasilkan dibawah kondisi kondisi (i) kenaikan efek refrigerasi, (ii) penurunan temparatur keluar kondensor, (iii) naiknya tekanan kerja compressor, dan (iv) kenaikkan tekanan kondensasi. Kenaikan tekanan kondensasi berhubungan dengan penurunan perbedaan temperature udara-refrigerant, koefisien perpindahan panas subcooling. Sifatsifat termodinamika yang berkaitan dengan naiknya efek refrigerasi, seperti panas spesifik cairan, panas laten evaporasi dominan menentukan maksimum COP sistem subcooling condensor.

Subcooling adalah suatu proses terjadinya pelepasan panas (kalor) yang lebih besar daripada yang dibutuhkan untuk kondensasi sehingga suhu refrigeran cair yang keluar dari kondensor lebih rendah dari suhu pengembunan dan berada pada keadaan cair super-dingin (cair terkompresi). Sedangkan superheated merupakan suatu keadaan dimana fluida kerja (refrigerant) telah menjadi uap seluruhnya jika terus dilakukan penambahan panas, sehingga terbentuk satu fasa saja yaitu fasa uap.

Mekanisme siklus sistem refrigerasi kompresi uap dengan dan tanpa subcooling digambarkan pada gambar berikut ini (Pottker and HRNJAK, 2012).

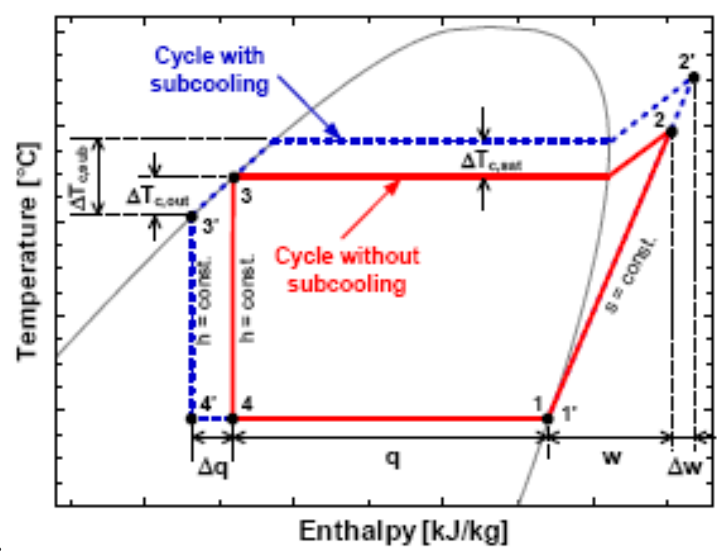

Figure 1. T-s Diagram Refrigeration Cycle

Dari Gambar 1, derajad kebebasan temperature subcooling adalah $\mathrm{T}_{3}-\mathrm{T}_{3}$, Jadi,

$$
\Delta T_{\mathrm{sub}}=T_{3}-T_{3^{\prime}}
$$

Efektivitas Subcooling Liquid-Suction ini diberikan oleh persamaan (Bolaji, 2010, Klein et.all, 2000, Prayudi, 2016), yaitu.

$$
\varepsilon=\frac{T_{\text {vapour, out }}-T_{\text {vapour,in }}}{T_{\text {liquid,out }}-T_{\text {vapour, in }}}=\frac{T_{1^{\prime}}-T_{1}}{T_{3}-T_{1}}
$$

Efek dari pemasangan penukar panas liquid-suction pada kapasitas pendinginan dapat diukur dalam hal indeks perubahan kapasitas relatif (RCI) sebagaimana didefinisikan dalam persamaan (Klein and Reindl, 2000).

$$
\mathrm{RCI}=\left(\frac{\mathrm{RC}_{\mathrm{sub}}-\mathrm{RC}}{\mathrm{RC}}\right) \times 100 \%
$$

dimana RCI adalah refrigeration capacity index, $\mathrm{RC}_{\text {sub }}$ adalah kapasitas refrigerasi dengan subcooling dan RC adalah kapasitas refrigerasi tanpa subcooling. Nilai kapasitas refrigerasi diberikan oleh (Bolaji,2010).

$$
\mathrm{RC}=\eta_{v} m\left(h_{1}-h_{4}\right)
$$

dan

$$
\mathrm{RC}_{\text {sub }}=\eta_{v} m\left(h_{1^{\prime}}-h_{4^{\prime}}\right)
$$

Efisiensi volume metrik pada persamaan (4) dan (5) dapat didekati degan rumus (Bolaji, 2010)

$$
\eta_{v}=1-R_{\text {inj }}\left(\frac{v_{1}}{v_{2}}-1\right)
$$

dimana $v_{1}$ dan $v_{2}$ masing-masing adalah volume specific refrigerant di suction dan discharge 
compressor, dan $\mathrm{R}_{i n j}$ adalah the ratio of the clearance volume to the displacement volume.

Efek dari penukar panas liquid-suction pada kerja compressor ini dapat diukur dari indeks perubahan kapasitas relatif (RWI) sebagaimana didefinisikan dalam persamaan (Prayudi, 2016).

$$
\mathrm{RWI}=\left(\frac{\mathrm{w}_{\mathrm{sub}}-w}{\mathrm{~W}}\right) x 100 \%
$$

dimana RWI adalah indeks perubahan kerja compressor relative, $\mathrm{w}_{\text {sub }}$ adalah kerja compressor dengan pemasangan penukar kalor subcooling dan $\mathrm{w}$ adalah kerja compressor tanpa penukar kalor subcooling. Dengan cara yang sama bahwa kenaikan kerja kompressor isentropic spesifik diberikan oleh persamaan (Potter and HRNJAK, 2012).

$$
\frac{\Delta w}{w}=\frac{h_{2}{ }^{\prime}-h_{2}}{h_{2}-h_{1}}
$$

Pendekatan lain yang digunakan untuk menghitung $\mathrm{COP}_{\text {sub }}$ dikenalkan oleh Prayudi (2016), meskipun penyerapan kalor ini terjadi pada saluran evaporator, kuantitas kalor yang diserap yaitu $\left(\mathrm{h}_{1}{ }^{\prime}-\mathrm{h}_{1}\right)$ tidak dihitung sebagai kapasitas pendinginan pada mesin pendingin, oleh karena kapasitas pendinginan dari evaporator tersebut diserap oleh subcooler pada outlet kondenser.

Sehingga nilai COP aktual mesin pendingin dengan subcool adalah,

$$
\mathrm{COP}_{\text {sub }}=\frac{h_{1}-h_{4^{\prime}}}{h_{2^{\prime}}-h_{1^{\prime}}}
$$

Sedangkan menurut program softwere CooldPack Ver 2.4, nilai $\mathrm{COP}_{\text {sub }}$ didefinisikan oleh persamaan,

$$
\mathrm{COP}_{\text {sub }}=\frac{h_{1^{\prime}}-h_{4^{\prime}}}{h_{2^{\prime}}-h_{1^{\prime}}}
$$

Selanjutnya untuk mengetahui perubahan $\mathrm{COP}$ dan $\mathrm{COP}_{\text {sub }}$ didefinisikanlah $\mathrm{COP}_{\mathbf{N}}$ yang diberikan oleh persamaan (Qureshi, 2012)

$$
\mathrm{COP}_{\mathrm{N}}=\frac{\mathrm{COP}_{\mathrm{sub}}}{\mathrm{COP}}
$$

\section{METODE PENELITIAN}

Penelitian ini menggunakan pendekatan metode eksperimental pada skala laboratorium. Mesin pendingin yang digunakan RTU Cold Strorage yang ada di Laboratorium Teknik Pendingin STT PLN dengan kompresor jenis Tecumseh/CAJ9480T, type Hermetic dengan refrigerant yang kompetibel adalah R.22, R404A,R134A， R407C dan R507A yang dirangan beroperasi pada temperature evaporasi sampai dengan $-40^{\circ} \mathrm{C}$. Kondensor yang digunakan Tecumseh/CAJ9480T, Shel and coils air coled condenser Pipa tembaga, Polycarbonat Panjang : $28 \mathrm{~cm}$, Tinggi : $24 \mathrm{~cm}$, Lebar :7 cm. Evaporator yang dgunakan Luvata, EVS40ED Shel and coils air coled evaporator $0.291 \mathrm{~kW}$ Panjang : $30 \mathrm{~cm}$, Tinggi : $10.5 \mathrm{~cm}$, lebar : $10 \mathrm{~cm}$ Heat Exchanger (HE) pipa tembaga Panjang : $60 \mathrm{~cm}, \mathrm{~d} 1=3 / 4$ inchi, $\mathrm{d} 1=1 / 4$ inchi

Sistem refrigerasi dengan penukar kalor subcooling liquid suction yang dikembangkan pada penelitian ini ini memiliki komponenkomponen seperti sistem refrijerasi pada umumnya, seperti kompresor, kondenser, katup ekapansi, dan kondenser. Ada beberapa penambahan Heat Exchanger yaitu Tube and Tube Heat Exchanger, sebagai alat penukar kalor antara fase liquid yang lebih rendah temperaturnya ke fase gas yang lebih tinggi temperaturnya. Sistem ini juga dilengkapi dengan alat ukur, aksesoris dan peralatan bantu lainnya seperti pressure gauge, pressure transmitter, thermokopel digital, oil separator, separator (untuk refrijeran), shut off valve, sight glass, dan filter dryer. Jumlah termokopel digital yang dipasang sebanyak 4 buah, dan 2 buah alar ukur tekanan, gambar alat uji terlibat pada gambar.

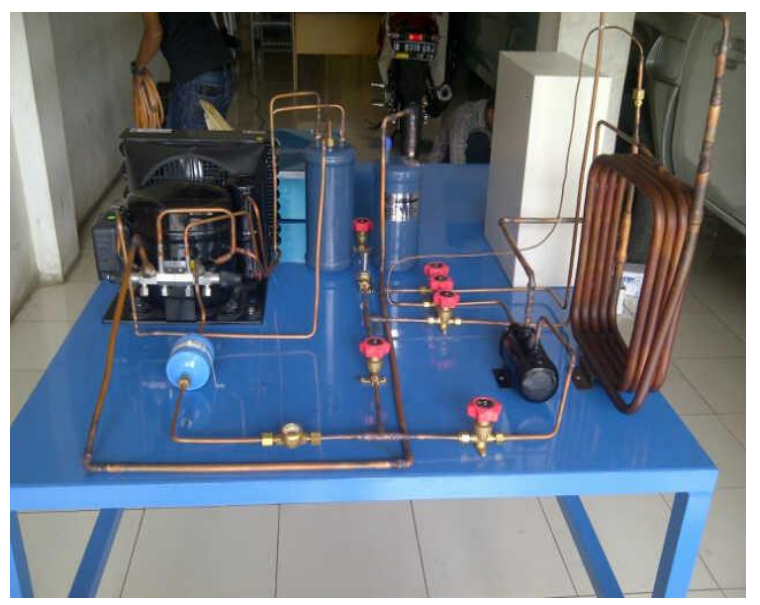

Gambar 2. RTU Colds Storage

\section{HASIL DAN PEMBAHASAN}

\subsection{Pengaruh Efektifivitas HE Subcool Terhadap $\Delta \mathrm{T}$ subcool}

Dari Gambar 3, besarnya efektivitas penukar kalor subcool ( $\varepsilon$-HE) berkisar antara 0 sampai 0.9. Dengan refrigerant R22 penukar 
kalor subcool berdampak pada $\Delta \mathrm{T}_{\text {sub }}$ bilamana $\varepsilon_{\mathrm{HE}}>0.25$, sedangkan pada kondisi $0.3<\varepsilon_{\mathrm{HE}}<$ 0.7 , hanya berdampak memberikan $\Delta \mathrm{T}_{\text {sub }}=1^{\circ} \mathrm{C}$. Untuk refrigerant $\mathrm{R} 22$, besarnya nilai $\Delta \mathrm{T}_{\text {sub }}$ maksimum $5^{\circ} \mathrm{C}$ yang terjadi pada $\varepsilon_{\mathrm{HE}}=0.8$. Bilamana menggunakan refrigerant R404A, semakin besar $\varepsilon_{\mathrm{HE}}$ artinya penukar kalor subcool semakin efektif, maka $\Delta \mathrm{T}_{\text {sub }}$ semakin meningkat. Bilamana $\varepsilon_{\mathrm{HE}}<0.7$, besarnya temperature subcooling $\Delta \mathrm{T}_{\text {sub }}$ maksimum $2^{\circ} \mathrm{C}$. Penukar aklor subcool efektif bilamana $\varepsilon_{\mathrm{HE}}>$ 0.7, dimana temperature subcoolingnya mencapai $\Delta \mathrm{T}_{\text {sub }}=10^{\circ} \mathrm{C}$.

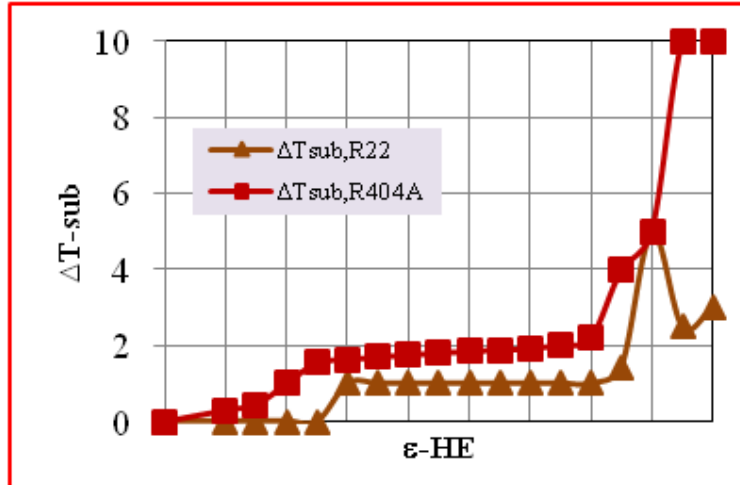

Gambar 3. Pengaruh e-HE terhadap dT

Dengan menggunakan pendekatan metode regresi linier, bahwa setiap kenaikan $\varepsilon_{\mathrm{HE}}$ sebesar 0.1 maka temperature subcooling akan naik sebesar $\quad \Delta \mathrm{T}_{\text {sub, } \mathbf{R} 22}=0.4788^{\circ} \mathrm{C}, \quad \Delta \mathrm{T}_{\text {sub,R404A }}=$ $0.9251^{\circ} \mathrm{C}$. Sehingga dengan refrigerant R404A penggunaan penukar kalor subcooling menghasilkan temperature subcooling lebih besar dari pada menggunakan R22.

\subsection{Pengaruh Efektivitas HE Subcool Terhadap}

Kapasitas Refrigerasi

Besarnya kapasitas refrigerasi pada kasus ini dihitung dengan menggunakan rumus (4) untuk kondisi tanpa penukar kalor subcool dan kapasitas refrigerasi untuk kondisi dengan penukar kalor subcool dengan menggunakan rumus (5). Rata-rata kapasitas refrigerasi R22 tanpa penukar kalor subcool adalah $\mathrm{RC}_{\mathbf{R} 22}=148.95 \mathrm{~kJ} / \mathrm{kg}$ dan dengan penukar kalor subcool, $\mathrm{RC}_{\text {sub,R22 }}=160.81 \mathrm{~kJ} / \mathrm{kg}$. Sedangkan menggunakan refrigerant $\mathrm{R} 404 \mathrm{~A}$ diperoleh, $\mathrm{RC}_{\mathbf{R} 04 \mathrm{~A}}=104.85 \mathrm{~kJ} / \mathrm{kg}$ dan $\mathrm{RC}_{\text {sub, R404A }}=128.42$ $\mathrm{kJ} / \mathrm{kg}$.

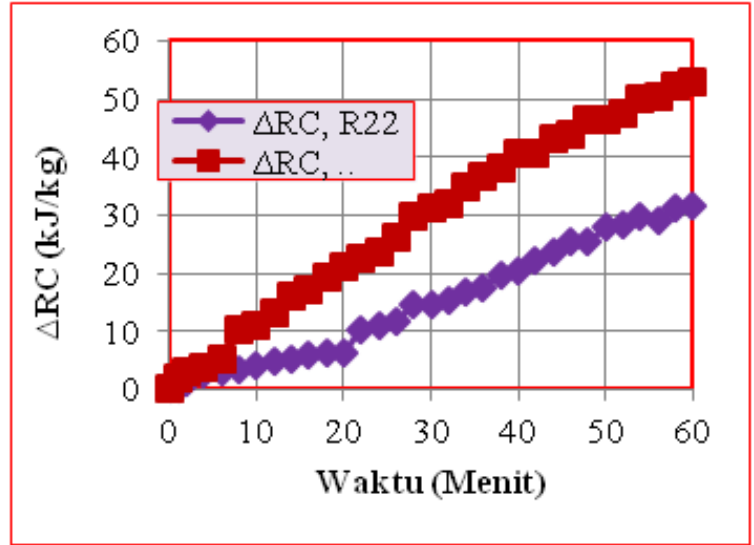

Gambar 3. Pengaruh $\varepsilon$-HE terdahap RCI (\%)

Bahwa pemasangan penukar kalor subcool meningkatkan kapasitas refrigerasi baik menggunakan refrigerant R22 maupun R404A, dan dengan menggunakan refrigerant R404A memberikan peningkatan kapasitas refrigerasi lebih besar dari pada menggunakan refrigerant $\mathrm{R} 22$ dimana $\Delta \mathrm{RC}_{\mathbf{R} 22}=31.46 \mathrm{~kJ} / \mathrm{kg}$ khususnya pada menit ke-60. Sedangkan dengan refrigerant R404A peningkatan kapasitas refrigerasinya lebih besar, misalnya pada menit ke-10, $\Delta \mathrm{RC}_{\mathbf{R 4 0 4 A}}=11.025 \mathrm{~kJ} / \mathrm{kg}$ lebih besar daripada $\Delta \mathrm{RC}_{\mathrm{R} 22}=4.182 \mathrm{~kJ} / \mathrm{kg}$.

Selanjutnya untuk melihat pengaruh efektivitas penukar kalor $\varepsilon_{\mathrm{HE}}$ terhadap peningkatan indeks kapasitas refrigerasi RCI digunakan Gambar 4. terlihat bahwa efekvitas penukar kalor semakin meningkat, maka indeks kapasitas refrigerasi juga meningkat. Rata-rata prosentase kanaikan kapasitas refrigerasi adalah $\mathrm{RCI}_{\mathrm{R} 22}=4.02 \%$, dan $\quad \mathrm{RCI}_{\mathrm{R} 404 \mathrm{~A}}=15.16 \%$. Selanjutnya dengan pendekatan metode regresi linier, hubungan antara RCI dan $\varepsilon_{\mathrm{HE}}$ untuk refrigerant R22 setiap kenaikan $\varepsilon_{\mathbf{H E}}$ sebesar 0.1 maka kapasitas refrigerasi akan naik sebesar $1.526 \%$, sedangkan setiap kenaikan $\varepsilon_{\mathrm{HE}}$ sebesar 0.1 maka prosentase peningkatan kapasitas refrigerasi akan naik sebesar $5.524 \%$. Sehingga dengan penggunaan refrigerant $\mathrm{R} 404 \mathrm{~A}$ dan penukar kalor subcooling menghasilkan prosentase peningkatan kapasitas refrigerasi yang lebih besar dari pada menggunakan R22. Dengan demikian ditinjau dari sudut pandang prosentase peningkatan kapasitas refrigerasinya dapat dikatakan bahwa penggunaan refrigerant R404A memiliki kinerja yang lebih baik dari pada menggunakan R22, sehingga dari sudut pandang pengaruh efektivitas penukar kalor terhadap prosentase peningkatan kapasitas 
refrigerasi refrigerant R404A dapat digunakan sebagai pengganti dari refrigerant R22.

\subsection{Pengaruh Efektivitas HE Terhadap Indeks}

Kerja Kompressor

Besarnya kerja compressor pada kasus ini dihitung dengan menggunakan rumus (7) untuk kondisi tanpa penukar kalor subcool dan menggunakan rumus (8) untuk kondisi dengan penukar kalor subcool. Rata-rata kerja compressor dengan refrigerai R22 diperoleh hasil $\mathrm{w}_{\mathbf{R} 22}=47.49 \mathrm{~kJ} / \mathrm{kg}$ dan $\quad \mathrm{w}_{\mathbf{R} 22, \text { sub }}=47.856$ $\mathrm{kJ} / \mathrm{kg}$. Sedangkan menggunakan refrigerant R404A diperoleh rata-rata kerja kompressornya adalah, $\mathrm{w}_{\mathbf{R} 404 \mathrm{~A}}=38.03 \mathrm{~kJ} / \mathrm{kg}$ dan $\mathrm{W}_{\mathbf{R} 404 \mathrm{~A}, \text { sub }}=40.15$ $\mathrm{kJ} / \mathrm{kg}$.

Dari data ini terlihat bahwa adanya subcool akan meningkatkan kerja compressor. Dengan menggunakan data-data pada lampiran berikut ini disajikan grafik pengaruh subcool terhadap kenaikan kerja compressor refrigerasi menurut waktu berikut ini.

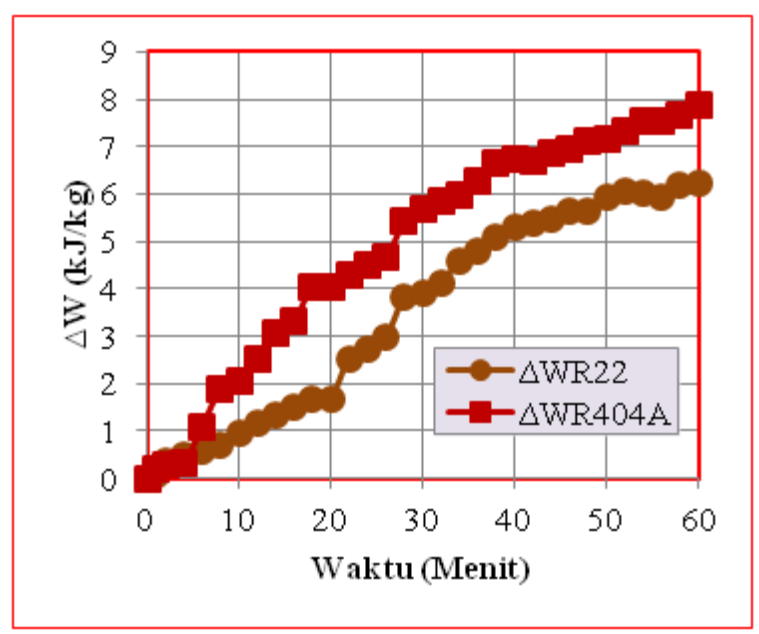

Gambar 5. Pengaruh Subcool Terhadap Kenaikan Kerja Kompressor

Dari Gambar 5. bahwa pemasangan penukar kalor subcool meningkatkan kerja compressor baik menggunakan refrigerant R22 maupun R404A dimana kecenderungan meningkat menurut waktu. Dari Gambar 5 terlihat bahwa dengan menngunakan refrigerant R404A memberikan dampak peningkatan kerja compressor yang lebih besar dari pada menggunakan refrigerant R22.

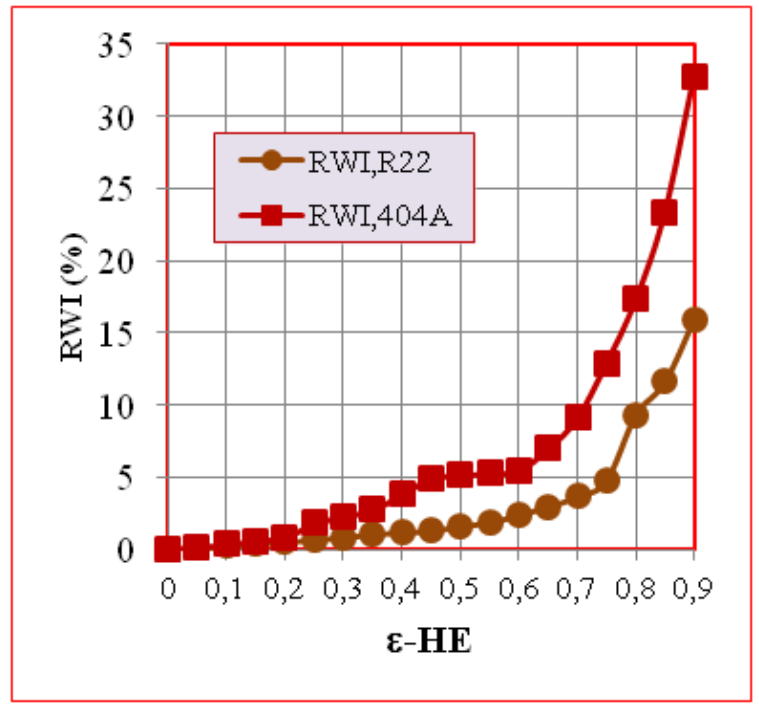

Gambar 6. Pengaruh $\varepsilon_{\mathrm{HE}}$ Terhadap RWI

Dari Gambar 5, dengan menggunakan refrigerant R22, peningkatan kerja komprssor mencapai $\Delta \mathrm{W}_{\mathbf{R} 22}=6.236 \mathrm{~kJ} / \mathrm{kg}$ khususnya pada menit ke-60. Sedangkan dengan refrigerant R404A peningkatan kerja kompressornya besar, misalnya pada menit ke-10, $\Delta \mathrm{W}_{\mathbf{R} 404 \mathrm{~A}}=2.402$ $\mathrm{kJ} / \mathrm{kg}$ lebih besar daripada $\Delta \mathrm{W}_{\mathbf{R} 22}=0.697 \mathrm{~kJ} / \mathrm{kg}$. Demikian pula menit ke-60 peningkatan kerja kompressor untuk R404A mencapai $\Delta \mathrm{W}_{\mathbf{R 4 0 4 A}}=7.862 \mathrm{~kJ} / \mathrm{kg}$ pada menit ke-60. Berdasarkan data pada lampiran, rata-rata kenaikan kerja kompresornya masing-masing adalah $\Delta \mathrm{w}_{\mathrm{R} 22}=3.405 \mathrm{~kJ} / \mathrm{kg}$, dan $\Delta \mathrm{w}_{\mathrm{R} 404 \mathrm{~A}}=4.736$ $\mathrm{kJ} / \mathrm{kg}$

Selanjutnya, dari Gambar 6 terlihat bahwa semakin besar efektivitas penukar kalor subcool, maka prosentase kenaikan kerja compressor juga semakin meningkat. Rata-rata prosentase kenaikan kerja kompresor untuk refrigerant R22 adalah $\mathrm{RWI}_{\mathrm{R} 22}=3.18 \%$, sedangkan untuk refrigerant $\mathrm{R} 404 \mathrm{~A}$ adalah $\mathrm{RWI}_{\mathrm{R} 404 \mathrm{~A}}=7.15 \%$. Selanjutnya dengan pendekatan metode regresi linier, hubungan antara RWI dan $\varepsilon_{\mathrm{HE}}$ untuk refrigerant R22 untuk setiap kenaikan $\varepsilon_{\mathrm{HE}}$ sebesar 0.1 maka prosentase kenaikan kerja compressor akibat pemasangan penukar kalor subcool untuk refrigerant R22 akan naik sebesar $\mathrm{RWI}_{\mathrm{R} 22}=1.251 \%$. Selanjutnya untuk R404A setiap kenaikan $\varepsilon_{\mathrm{HE}}$ sebesar 0.1 maka prosentase peningkatan kerja compressor untuk refrigerant R404A relative terhadap system akan naik sebesar $\mathrm{RWI}_{\mathbf{R} 404 \mathrm{~A}}=2.635 \%$. Sehingga dengan penggunaan refrigerant R404A dan penukar kalor subcooling menghasilkan prosentase peningkatan COP relative terhadap system lebih besar dari pada menggunakan R22. Dengan 
demikian ditinjau dari sudut pandang prosentase peningkatan COP dapat dikatakan bahwa penggunaan refrigerant R404A ada kemungkian akan berdampak pada penurunan kinerja dibandingan menggunakan R22

\subsection{Pengaruh Efektivitas HE Subcool terhadap Relatif COP}

Pada analisis ini, COP tanpa penukar kalor subcool dihitung dengan rumus (9), COPsub dihitung dengan rumus (10), dan $\mathrm{COP}_{\mathbf{R S}}$ dihitung dengan menggunakan rumus (11). Sedangan efektivitas penukar kalor dihitung dengan rumus (8). Dengan menggunakan data pada lampiran, untuk R22 rata-rata COP actual adalah $\mathrm{COP}=3.14$ dan $\mathrm{COP}$ dengan pengukar kalor subcool rata-rata $\mathrm{COP}_{\text {sub }}$ adalah $\mathrm{COP}_{\text {sub }}=3.379$. Demikian pula untuk R404A rata-rata $\mathrm{COP}$ actual adalah $\mathrm{COP}=2.76$, dan COP dengan penukar kalor subcool rata-rata $\mathrm{COP}_{\text {sub }}$ adalah $\mathrm{COP}_{\text {sub }}=3.19$. Dengan demikian dapat disimpulkan bahwa pemasangan penukar kalor subcool efektif meningkatkan kinerja refrigerasi (COP).

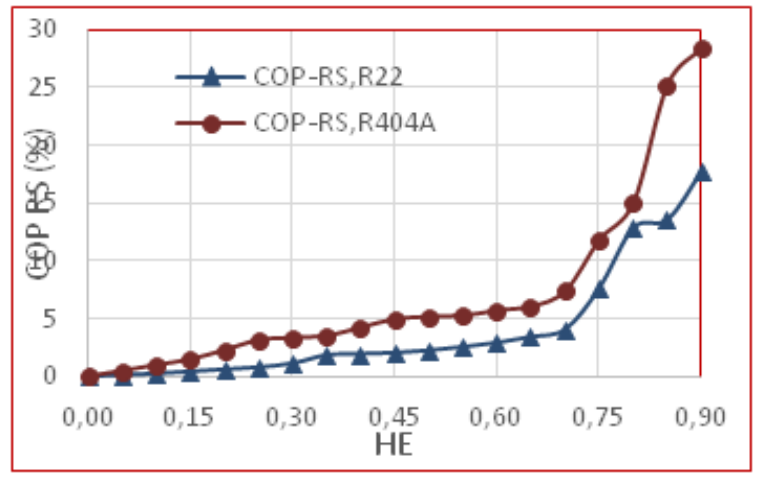

Gambar 7. Pengaruh $\varepsilon_{\mathrm{HE}}$ Terhadap $\mathrm{COP}_{\mathrm{RS}}$

Guna melihat efektivitas penukar kalor terhadap peningkatan COP dapat dilihat dengan membuat grafik hubungan anatara efektivitas penukar kalor subcool $\varepsilon_{\mathrm{HE}}$ dan prosentase

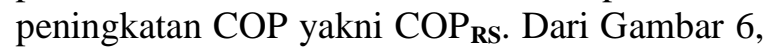
rata-rata RS-COP untuk refrigerant $\mathrm{R} 22$ adalah $4.04 \%$ dan R404A 7,07\% artinya dampak pemasangan penukar kalor subcool akan mengakibatkan $\mathrm{COP}_{\mathbf{R 2 2}}$ meningkat sebesar $4,04 \%$ dan $\mathrm{COP}_{\mathbf{R 4 0 4 A}}$ meningkat sebesar 7,07\%.

Selanjutnya dengan pendekatan metode regresi linier, hubungan antara $\mathrm{COP}_{\mathbf{R S}}$ dan $\varepsilon_{\mathbf{H E}}$ untuk refrigerant R22 setiap kenaikan $\varepsilon_{\mathbf{H E}}$ sebesar 0.1 maka prosentase kenaikan COP akibat pemasangan penukar kalor subcool untuk refrigerant R22 akan naik sebesar $\mathrm{COP}_{\mathrm{RS}, \mathrm{R} 22}=1.533 \%$, sedangkan untuk $\mathrm{R} 404 \mathrm{~A}$ setiap kenaikan $\varepsilon_{\mathrm{HE}}$ sebesar 0.1 maka prosentase peningkatan COP untuk refrigerant R404A terhadap system akan naik sebesar $\mathbf{C O P}_{\mathbf{R S}, \mathbf{R} 404 \mathrm{~A}}=$ $2.324 \%$. Sehingga dengan penggunaan refrigerant R404A dan penukar kalor subcooling menghasilkan prosentase peningkatan COP relative terhadap system lebih besar dari pada menggunakan R22. Dengan demikian ditinjau dari sudut pandang prosentase peningkatan $\mathrm{COP}$ dapat dikatakan bahwa penggunaan refrigerant R404A memiliki kinerja yang lebih baik dari pada menggunakan R22, sehingga dari sudut pandang pengaruh efektivitas penukar kalor terhadap prosentase peningkatan COP refrigerant R404A dapat digunakan sebagai pengganti dari refrigerant R22.

\subsection{Analilis Kinerja mesin Pendingin}

Berdasarkan hasil analisis dari diatas berikut ini disajikan analisis secara umum pengaruh subcool terhadap kinerja mesin RTUClod storage mini. Analisis keseluruhan pengaruh pamsangan penukar kalor subcool ditinjau dari kenaikan dan atau penurunan parameter-parameter unjuk kerja mesin RTU Cold Storage mini. Parameter-parameter yang digunakan untuk melakukan analisis keseluruhan yaitu.

(1) Perubahan temperature dan tekanan dampak pemasangan penukar kalor subcool

(2) Pengaruh efektivitas penukar kalor subcool $\left(\varepsilon_{\mathrm{HE}}\right)$ terhadap temperature subcool $\left(\Delta \mathrm{T}_{\mathrm{sub}}\right)$

(3) Pengaruh subcool terhadap terhadap kenaikan kapasitas refrigerasi $(\triangle \mathrm{RC})$ dan pengaruh efektivitas penukar kalor subcool $\left(\varepsilon_{\mathrm{HE}}\right)$ terhadap indeks kapasitas refrigerasi (RCI)

(4) Pengaruh subcool terhadap kenaikan kerja compressor $(\Delta \mathrm{W})$ dan pengaruh efektivitas penukar kalor subcool $\left(\varepsilon_{\mathrm{HE}}\right)$ terhadap indeks kerja kompressor (RWI)

(5) Pengaruh subcool terhadap kenaikan COP dan pengaruh efektivitas penukar kalor subcool $\left(\varepsilon_{\mathrm{HE}}\right)$ dan prosentase kenaikan $\mathrm{COP}$ $\left(\mathrm{COP}_{\mathrm{RS}}\right)$

Berdasarkan parameter-parameter diatas, pada table berikut ini menyajikan ringkasan hasil analisis dari sub bab sebelumnya, yang disajikan pada table berikut ini. 
Tabel 1. Parameter Kinerja RTU Cold Storage

\begin{tabular}{|c|c|c|c|c|c|}
\hline \multirow[b]{2}{*}{ No } & \multirow[b]{2}{*}{ Parameter Kinerja } & \multicolumn{2}{|c|}{ R22 } & \multicolumn{2}{|c|}{ R404A } \\
\hline & & $\begin{array}{c}\text { Tanpa } \\
\text { HE } \\
\text { Subcool }\end{array}$ & $\begin{array}{c}\text { Dengan } \\
\text { HE } \\
\text { Subcool }\end{array}$ & $\begin{array}{c}\text { Tanpa } \\
\text { HE } \\
\text { Subcool }\end{array}$ & $\begin{array}{l}\text { Dengan } \\
\text { HE } \\
\text { Subcool }\end{array}$ \\
\hline 1 & $\begin{array}{l}\text { Temperatur evaporator pada kondisi steady state } \\
\left({ }^{\circ} \mathrm{C}\right)\end{array}$ & -13.3 & -15.1 & -16.4 & -21.2 \\
\hline \multirow{3}{*}{2} & Tekanan compressor & & & & \\
\hline & - Tekanan masuk (bar) & 2.73 & 2.94 & 3.01 & 2.91 \\
\hline & - Tekanan keluar (bar) & 16.52 & 16.52 & 17.69 & 16.67 \\
\hline \multirow[t]{5}{*}{3} & Kapasitas Refrigerasi per kg-massa refrigerant & & & & \\
\hline & - Rata-rata kapasitas refrigerasi $(\mathrm{kJ} / \mathrm{kg})$ & 148.95 & 160.861 & 104.85 & 128.42 \\
\hline & $\begin{array}{l}\text { - Rata-rata peningkatan kapasitas pendinginan } \\
(\mathrm{kJ} / \mathrm{kg})\end{array}$ & & 14.69 & & 28.43 \\
\hline & - Rata-rata Indeks kapasitas refrigerasi RCI (\%) & & 4.02 & & 15.16 \\
\hline & - Kemiringan/slope $\varepsilon$-HE terhadap RCI & & 15.26 & & 55.24 \\
\hline \multirow[t]{4}{*}{5} & Kerja kompresor per kg-massa refrigerant & & & & \\
\hline & - Rata-rata kerja kompressor $(\mathrm{kJ} / \mathrm{kg})$ & 47.49 & 47.586 & 38.03 & 40.15 \\
\hline & $\begin{array}{l}\text { - Rata-rata Indeks Perubahan Kerja Kompresosor } \\
\text { RWI }(\%)\end{array}$ & & 3.18 & & 7.15 \\
\hline & - Kemiringan/slope $\varepsilon$-HE terhadap RWI & & 12.51 & & 26.35 \\
\hline \multirow[t]{4}{*}{6} & $\mathrm{COP}$ & & & & \\
\hline & - Rata-rata COP & 3.14 & 3.38 & 2.76 & 3.19 \\
\hline & - Rata-rata kenaikan COP $(\%)$ & & 4.03 & & 7.08 \\
\hline & - Kemiringan/slope $\varepsilon$-HE terhadap $\mathrm{COP}_{\mathrm{RS}}$ & & 15.33 & & 23.24 \\
\hline
\end{tabular}

\section{KESIMPULAN}

Berdasarkan parameter kinerja RTU pada table 1 dan analisis, secara umum dapat disimpulkan bahwa :

- Temperatur evaporator pada kondisi stabil dengan R404A lebih rendah dari pada R22 baik menggunakan atau tanpa penukar kalor subcool.

- Kapasitas refrigerasi dengan refrigerant R22 lebih besar daripada menggunakan R404A, dan adanya penukar kalor subcool rata-rata kenaiakan refrigerasi R404A lebih besar dari pada R22.

- Kerja kompresor dengan refrigerant campuran R290/R600a lebih besar daripada R404a, dan adanya subcool kerja compressor reltif tidak berubah

- COP dengan campuran R290/R600a lebih besar daripada R404a, dan adanya subcool akan mengakibatkan COP menurun

- Dengan memperhatikan karakterik kinerja diatas secara umum dapat dikatakan bahwa R404A dapat digunakan sebagai pengganti dari R22

\section{UCAPAN TERIMA KASIH}

Penelitian ini mendapatkan dana hibah internal STT-PLN untuk tahun anggaran 2017/2018, oleh karena itu Tim Peneliti mengucapkan kepada Ketua LPPM STT-PLN atas kepercayaan dan pendanaanya sehingga penelitian ini dapat terlaksana dengan baik.

\section{REFERENSI}

(1) Austin N., Kumar P.S., Kanthavelkumaran N., Thermodynamic Optimazation of household refrigerator using Propana-Butana as mixed refrigerant, Research and Aplication (IJERA), Vol 2, Issue 6 NovemberDesember 2012, pp. 268-271

(2) Bolaji B.O., Performance of A R22 splitair-contioner when retrofitted with ozone friendly refrigerant (R410A and R417a), Journal of Energi in Southern Africa, Vol 23 No 3, pp 16-23, 2012

(3) Bolaji B.O., Akintunde M.A., Falade T.O, Theoretical Onvestigation of the Performance of Some EnvoronmentFriendly Refrigerants ins Sub-Cooling 
Heat Exchanger Refrigeration System, Journal of Science and Technology, Vol 30, No. 3, pp.101-108, 2010

(4) Bolaji B.O., Zhongjie H, Thermodynamic analysis of hydrocarbon refrigerants in a sub-cooling refrigeration system, Journal of Engineering Research, Vol 1 No 1 June 2013, pp. 317-333, 2013

(5) Domanski P.A., Didion D.A., Doyle J.P., Evaluation of Suction Line-Liquid Line Heat Exchange in the Refrigeration Cycle, International Refrigeration and Air Conditioning Conference, Paper 149, pp. 131-139, Purdue e-Pubs Purdue University, 1992

(6) Gong M.Q., Wu J.F, Luo E.G., Performance of the mixed gas JouleThomson refrigeration cycles for cooling fixed-temperature heat loads, Cryogenics Vo 44. pp 847-857, Elseviar, 2004

(7) Hadya B., Sri P.U., Akella S., Comparative study of eco-friendly refrigerants in a lower capacity airconditioning system, International Conference on Mechanichal and Aoutomotive Engineering (ICAME2012), September 8-9, 2012, Bangkok

(8) Jadhav S.S., Mali K.V., Evaluation of A Refrigerant R410A as substitute for R22 in Windows air-conditioner, IOSr Journal of Mechanical and Civil Engineering, pp.23-32, ISSN : 2278-1684, 2012

(9) Klein S.A., Reindl, D.T., and Brownell K., Refrigeration System Performance using Liquid-Suction Heat Exchangers, International Journal of Refrigeration, Vol. 23, Part 8, pp. 588 - 596 (2000).

(10) Mohanraj S.J., Muraleedharan C., Environment friendly alternatives to halogenated refrigerants, A review, International Journal of Greenhouse Gas Control Vol 3, pp. $108-11$ 9, Science Direct, Elsesiar, 2009

(11) Motta S.F.Y., Domanski P.A., Performance of R-22 and its alternatives working at high outdoor temperature, Eighth International Refrigeration Conference at Purdue University, July, 2000 pp.47-54

(12) Poltker G., Hrnjak P.S, Effect of Condenser Subcooling of the Performance of Vapor Compression Systems:Experimental and Numerical Investigation, International Refrigeration and Air Conditioning Conference, July 16-19, 2012, Purdue e-Pubs, 2012.

(13) Paharia A.K., Gupta R.C., Effect of Sub Cooling and Superheating on Vapor Compression Refrigerator Systems Using R-22 Alternative Refrigerants, International Journal od Emerging Trnes in Engineering and Development, Issue 3, Vol 1 Januari 2013, ISSN : 2249-6149, 2013

(14) Prayudi, Nurhasanah N, Analysis od Effect of Subccoling Performance of Vapor Compression Refrigerations System With Cooling Load Variation, ARPN Journal of Enggineering and Applied Sciences, ISSN : 1819-7708, Vol 11 No. 2 January 2016,

(15) Qureshi B.A., Syed M.Z., The effect of refrigerant combinations on performance of a vapor compression refrigeration system with dedicated mechanical subcooling, Internatinal Journal of Refrigeration, Vol 35. Pp. 47-57, Elseviar, 2012

(16) Rocca V.L., Panno G., Experimental performance evaluation ofa vapor compression refrigerating plant when replacing R22 with alternative refrigerants, Journal Applied Energy Vol. 88 pp. 2809-2815, 2011

(17) Sattar M.A., Saidur R., Masjuki H.H., Performance investigation of domestic refrigerator using pure hydrocarbons and blends of hydrocarbons as refrigerant, Word Academy of Science Engineering and Technology Vol 5, pp. 223-228, 2007

(18) Thangeval, P, et.all, Simulation analysis of compression refrigeration cycle with different refrigerant, International Journal of Engineering and Innovative Technology, Vol 2, Issue 10, April 2013, pp 127-131, ISSN : 2277-3755, 2013

(19) Thangavel P., Somasundaram, Effects Ovaporator loas on vapor compression refrigeration system using eco friendly hydrocarbon refrigerants with sub cooling, Journal of Scientific and Industrial Recearch, Vol 72, November 2013, pp. 695-702, 2013

(20) Thangavel P., Somasundaram P., Simulation Analysis of Compression Refrigeration Cycle with Different Refrigerants, International Journal of Engineering and Innovative Technology, 
Volume 2, Issue 10, April 2013, ISSN : 2277-3754 pp. 127-131, 2013

(21) Thornton J.W., Klein S.A., Mithchell J.W., Dedicated Mechanical Subcooling Design Strategies for Supermarket Aplications, International Refrigeration and Air Conditioning Conference, Paper 191, pp 521-530, Purdue e-Pubs Purdue University, 1992

(22) XU L., HRNJAK P., Potential for Improving Efficiency by Controlling Subcooling in Residential A/C System, International Refrigeration and Air Conditioning Conference at Purdue, July 14-17, 2014, Paper 2387, 2014

(23) Wankhede U.S., COP improment of air conditioning system using evaporative condenser, International Journal of Applied Engineering Research, Vol. 4, No. 3, 2009, pp 363-370, ISSN : 09734562 ,

http://www.ripublication.com/ijern.htm, 2009.

(24) Wongwices S., Chimres N., Experimental study of hydrocarbon mixture to replace HFC-134a in a domestic refrigerator, Energy Conversion and Management, Vol 45, Elvisar, 2005 pp. 85-100, 2005 